\title{
METÁFORAS CONCEPTUAIS COMO FERRAMENTAS DE ARGUMENTAÇÃO E PERSUASÃO NO DISCURSO JURÍDICO
}

\author{
Lidiane Melo de Souza ${ }^{1}$ \\ Monica Fontenelle Carneiro ${ }^{2}$
}

\section{RESUMO}

O presente estudo, inserido no campo da Linguística Cognitiva e do Direito, pretende identificar e analisar a presença de metáforas conceptuais como ferramentas de argumentação e persuasão no discurso jurídico. Em termos metodológicos, pauta-se basicamente na pesquisa bibliográfica, documental e na análise cognitivo-discursiva. Esclarece que, para o operador do Direito, a linguagem tem um papel fundamental pela necessidade de dominar o vocabulário da ciência do Direito de forma persuasiva, expressando argumentos de convencimento para sustentar teses. Analisa o discurso persuasivo através do uso da metáfora em virtude de sua capacidade de mediação entre a cognição e a emoção.

Palavras-chave: Metáfora Conceptual. Discurso Jurídico. Persuasão. Argumentação. Análise do Discurso.

\section{CONCEPTUAL METAPHORS AS TOOLS OF ARGUMENTATION AND PERSUASION IN LEGAL DISCOURSE}

\begin{abstract}
The present study, inserted in the field of Cognitive Linguistics and Law, intends to identify and analyze the presence of conceptual metaphors as tools of argumentation and persuasion in the legal discourse. In methodological terms, it is basically based on bibliographic, documentary research and cognitive-discursive analysis. It clarifies that, for the Law operator, language plays a fundamental role due to the need to dominate the vocabulary of Law science in a persuasive way, expressing convincing arguments to support theses. It analyzes persuasive speech through the use of metaphor due to its ability to mediate between cognition and emotion.

\footnotetext{
1 Mestranda do Programa de Pós-Graduação em Direito e Instituições do Sistema de Justiça da Universidade Federal do Maranhão (UFMA). E-mail: lmelo12345@ hotmail.com.

2 Professora Doutora e Mestre em Linguística pela Universidade Federal do Ceará (UFC). Professora do Departamento de Letras - DELER - e do quadro permanente dos Programas de Pós-Graduação em Letras PPGLETRAS (Campus de São Luís) e PPGLB (Campus de Bacabal) da Universidade Federal do Maranhão (UFMA). Professora colaboradora do PPGDIR - Programa de Pós-Graduação em Direito da Universidade Federal do Maranhão (UFMA).
} 
Keywords: Conceptual Metaphor. Legal Speech. Persuasion. Argumentation. Speech analysis.

\section{INTRODUÇÃO}

Cada profissão utiliza uma terminologia própria, sem a qual a execução satisfatória do trabalho seria impossível. Dessa forma, cabe ao profissional de cada área do conhecimento o dever inescusável de dominar a terminologia que caracteriza seu ofício, linguagem essa especial, diferenciada, técnica, capaz de identificar aqueles que são conhecedores de um saber. No caso do operador do Direito, a linguagem tem um papel fundamental, uma vez que, além da necessidade de dominar o vocabulário da ciência do Direito, esse profissional, no exercício da profissão, precisa se comunicar de forma persuasiva, expressando seus argumentos de convencimento, seja na defesa dos interesses de uma das partes, seja nas manifestações opinativas, seja no ato de decidir. O uso inadequado e equivocado da linguagem poderá causar dificuldades, não só para o profissional do direito como também para a parte. O motivo que leva o cidadão ao Judiciário precisa estar bem compreendido e a decisão judicial, por sua vez, deve ser construída de forma clara e fundamentada, explicitando os seus argumentos de convencimento.

Os profissionais do Direito fazem uso de termos específicos, em que as palavras são utilizadas de forma diferenciada daquela própria da comunicação cotidiana, deixando, por vezes, o interlocutor, que não conhece o significado desse vocabulário, à margem de seu contexto. Trata-se de uma linguagem especializada, própria de um saber do campo técnicocientífico.

Como dito anteriormente, uma característica essencial da linguagem jurídica é seu caráter altamente persuasivo. Diante disso, a capacidade de manipular palavras de forma a sustentar teses, maximizar e minimizar argumentos é uma habilidade essencial aos profissionais do Direito. É por meio da linguagem que o operador do Direito interage com o outro na tentativa de levá-lo a aceitar o que está sendo dito e a fazer o que está sendo proposto. Dessa forma, pode-se dizer que a linguagem jurídica é revestida de intencionalidade: quem fala o faz para alcançar determinado objetivo. Posto isto, justifica-se a 
busca, por parte do profissional de Direito, de uma melhor elaboração de seu discurso para torná-lo mais persuasivo e convincente.

Charteris-Black (2004) argumenta que uma importante característica do discurso persuasivo é o uso da metáfora, em virtude da sua capacidade de mediação entre os meios conscientes e inconscientes de persuasão, ou seja, entre a cognição e a emoção, no intuito de criar uma perspectiva moral sobre a vida. $\mathrm{O}$ autor defende que a metáfora é capaz de influenciar nossas crenças, atitudes e valores, em razão da sua capacidade de ativar relações emocionais inconscientes entre o domínio fonte e o domínio alvo ${ }^{3}$, de forma que possamos transferir associações negativas ou positivas do primeiro para o segundo. O propósito de persuadir pode estar camuflado, mas é sempre central em determinados discursos, tais como o político, o religioso e o jurídico, este último, foco da discussão que aqui propomos.

Partindo dessas premissas, o objetivo principal deste trabalho é responder à seguinte problemática: As metáforas conceptuais são capazes de subsidiar uma melhor compreensão do discurso jurídico considerando o seu caráter persuasivo?

A partir dos pressupostos discutidos, o presente trabalho busca analisar o papel das metáforas conceptuais no discurso jurídico no que tange à argumentatividade e à persuasividade desse discurso, realçando os pensamentos não revelados de forma intencional.

Compreendemos que um aprofundamento dessa questão pode ajudar a desvendar os argumentos não explicitados relacionados ao discurso jurídico na defesa de uma tese. Para tanto, nos apoiaremos em dois eixos teóricos principais, quais sejam, o discurso jurídico e a teoria da metáfora conceptual, que serão abordados adiante.

\section{DISCURSO JURÍDICO}

A linguagem jurídica é um meio comunicativo especial, técnico-científico e lógico, utilizado pelos operadores do Direito no exercício de suas funções, em nível culto, sendo que o dado estilístico de suas composições textuais deve traduzir uma preocupação formal e, em mesmo nível, um cuidado material, de conteúdo e sentido. O Direito sempre foi considerado ciência hermética, reservada para os iniciados em suas lides. Contudo, essa ciência não

\footnotetext{
3 Os conceitos de domínio fonte e domínio alvo serão discutidos em seção posterior quando abordarmos a Teoria da Metáfora Conceptual, mas podemos adiantar que domínio fonte é aquele a partir do qual conceptualizamos alguma coisa metaforicamente, ao passo que domínio alvo é aquele que desejamos conceptualizar (SARDINHA, 2007).
} 
Lidiane Melo de Souza \& Monica Fontenelle Carneiro

pertence somente aos profissionais da lei, mas também, às partes, normalmente pessoas leigas nos assuntos jurídicos. Na medida em que uma ciência começa a trabalhar rente à população, abre-se e democratiza-se sua linguagem àqueles que dela necessitam.

Embora haja uma tendência de tornar o discurso jurídico mais inteligível para os leigos, ainda falta muito para que a linguagem jurídica seja associada à linguagem cotidiana, por se tratar de um discurso mais aprimorado a um maior conhecimento técnico do assunto em análise. Há maior necessidade de habilidade retórica dos profissionais do Direito no seu desempenho linguístico, na medida em que a prática forense exige um nível de comunicabilidade acima da média, pautado na conjugação do gestual, da oralidade e da verbalização (SCHOCAIR, 2008).

Fetzner (2012) adverte que, embora os termos técnicos devam ser utilizados em virtude de sua necessidade em determinados contextos, o importante no texto não é a sofisticação da linguagem, mas a clareza, a concisão, a qualidade dos argumentos apresentados, organizados mediante um raciocínio lógico e coerente, originados de uma seleção madura de fatos relevantes que compõe o caso concreto.

Assim, deve o operador do Direito transmitir através da linguagem seus argumentos de convencimento de forma clara, exaltando os pontos fortes que possam respaldar a sua tese.

Nessa perspectiva, importa destacar que o uso das metáforas está intimamente relacionado com a compreensão do pensamento esboçado pelo operador do Direito e no seu entendimento descrito no texto. A linguagem jurídica, embora revestida de intencionalidade, voltada para elaboração de um discurso persuasivo, expressa, através do uso das metáforas, significações aparentemente não reveladas, mas que são capazes de induzir o leitor a uma compreensão diversa daquela que se encontra explícita no texto.

\section{TEORIA DA METÁFORA CONCEPTUAL}

Lakoff e Johnson (2002) apresentam um novo paradigma em que a metáfora deixa de ter um status de simples figura de linguagem e passa a ter seu valor cognitivo reconhecido.

Na verdade, Lakoff e Johnson (2002) seguiram o caminho aberto por Reddy (1979), que analisou rigorosamente enunciados linguísticos em seu ensaio "The conduit metaphor", traduzido como "A metáfora do canal", publicado na coletânea "Metaphor and thought", de Ortony (1979). Para eles os enunciados analisados por Reddy (1979) são manifestações 
linguísticas de metáforas conceptuais, sendo a metáfora do canal uma metáfora complexa constituída por uma rede de metáforas conceptuais. O avanço de Lakoff e Johnson (2002) com relação à Reddy (1979) está na questão de que eles analisaram amplamente enunciados da linguagem cotidiana e descobriram que nossa linguagem mostra um imenso sistema conceptual metafórico, que rege também nosso pensamento e nossa ação. A metáfora do canal, ao contrário, não se aplica às situações em que o contexto se faz necessário para determinar se a frase tem significado ou não.

O novo paradigma proposto por Lakoff e Johnson (2002) apresenta a metáfora como sendo um fenômeno central na linguagem e no pensamento, estando presente em todos os tipos de linguagem, inclusive na linguagem científica, conforme mencionado anteriormente. Para esses teóricos, nós compreendemos o mundo, a cultura e a nós mesmos por meio de metáforas, pois além de conceitos emocionais, como amor ou raiva, conceitos básicos, como tempo, quantidade, etc., são compreendidos metaforicamente. A tese central dessa teoria é a de que as metáforas existem em nossa mente, sendo os conceitos abstratos, em sua maioria, metafóricos. A língua é secundária. O pensamento e a razão são superiores à língua.

De acordo com Sardinha (2007), os conceitos principais dessa teoria são:

1) Metáfora conceptual: um modo de conceitualizar algo no mundo.

Exemplo: BOM É PARA CIMA.

2)Expressão metafórica: expressão linguística que mostra uma metáfora conceptual. Exemplo: Hoje estou com um alto astral. É uma expressão que advém da metáfora conceptual: BOM É PARA CIMA.

3)Domínio: relacionado ao conhecimento e experiência das pessoas. Existem dois tipos de domínio: fonte e alvo. O domínio-fonte é o domínio mais concreto a partir do qual conceituamos algo metaforicamente. O domínio-alvo é abstrato, ou seja, aquele que desejamos conceitualizar.

4) “Um mesmo domínio-fonte pode servir a vários domínios-alvo” (SARDINHA, 2007, p. 31).

5)Mapeamentos: as relações estabelecidas entre os domínios.

6)Desdobramentos: as diversas inferências que podem ser feitas com base em uma metáfora conceptual.

Os tipos de metáforas conceptuais são: 
Lidiane Melo de Souza \& Monica Fontenelle Carneiro

1) Estruturais: aquelas que são produtos de mapeamentos complexos. "Este grupo particular de metáforas consiste na estruturação metafórica de um conceito em termos de outro, que se projeta sobre aquele" (ABRANTES, 2001, p. 324). Exemplo: TEMPO É DINHEIRO.

Não percas mais tempo com este assunto.

Não posso investir mais tempo nesse projeto.

2) Orientacionais: são aquelas que dão a um conceito uma orientação espacial. Exemplo: O BEM ESTÁ À FRENTE.

Ele está à frente dos negócios. Há que seguir em frente.

3)Ontológicas: são aquelas que tornam concretos conceitos abstratos, porém sem estabelecer mapeamentos. Essa concretização se manifesta em termos de uma entidade (algo contável).

Exemplo: O TEMPO É UM CONTENTOR.

Estou de volta dentro de três dias.

Terminou o trabalho num curto espaço de tempo.

4)Personificação: são metáforas ontológicas, cuja entidade deve ser necessariamente uma pessoa.

Exemplo: UMA TEORIA É UMA PESSOA.

A teoria diz que...

5)Primárias: metáforas relacionadas a aspectos físicos do corpo humano, presentes em muitas culturas.

Exemplo: INTIMIDADE É PROXIMIDADE.

Podemos ainda destacar outros aspectos importantes dessa teoria. A teoria da metáfora conceptual postula que não existem verdades absolutas, devido ao fato de as metáforas serem culturais, ou seja, reflexo da ideologia de determinado grupo de pessoas, construída em determinada cultura. Mesmo as metáforas básicas, como as primárias e orientacionais, podem ser diferentes de uma cultura para outra. Outro fator importante, que já destacamos acima, é o de que a metáfora é uma representação mental e abstrata que se materializa na fala e na escrita por meio das expressões metafóricas. As metáforas conceptuais são, ainda, convencionais, ou seja, inconscientes, pois estão tão impregnadas em nossa cultura, que não nos damos conta do uso que fazemos delas. 
Lakoff e Johnson (2002, p. 348) fundamentam a concepção de metáfora naquilo que chamam de mito experiencialista, afirmando que,

O mito experiencialista considera o homem como parte do meio, não separado dele, e focaliza a constante interação do homem com o ambiente físico e com as outras pessoas. Vê essa interação com o meio envolvendo a transformação mútua. Ninguém pode agir no meio sem transformá-lo ou sem ser transformado por ele.

Daí a justificativa das metáforas serem parte da linguagem cotidiana, essenciais ao nosso processo de conceptualizar o mundo.

Segundo Kövecses (2002), a metáfora conceptual é constituída de dois domínios conceptuais onde um domínio é compreendido em termos de outro. Essa compreensão de um domínio em termos de outro envolve uma série de mapeamentos (correspondências) entre o domínio-alvo e o domínio-fonte. Esses mapeamentos derivam de um mapeamento central, que é o responsável pelo significado principal dos domínios-fonte e dos domínios-alvo. Assim, os mapeamentos centrais desempenham as seguintes funções: na função conceptual, favorecem o surgimento de outros mapeamentos; culturalmente, refletem os principais conceitos humanos relacionados ao domínio-fonte em questão; motivacionalmente, são motivados na maioria das vezes em aspectos experienciais, sejam eles físicos ou culturais; linguisticamente, fazem surgir expressões metafóricas que dominam uma metáfora.

Com relação ao domínio-fonte e domínio-alvo, Kövecses (2002) afirma que cada domínio-fonte é designado a cumprir uma função específica na caracterização de vários domínios-alvo, ou seja, cada domínio-fonte é associado com um significado particular que é mapeado em direção a um domínio-alvo. Esse significado é convencionalmente fixado e aceito dentro do discurso de determinada comunidade linguística. O domínio-alvo recebe o significado principal do domínio-fonte. Geralmente, o domínio-fonte constitui-se de uma situação intensa, como ações, eventos ou estados.

De acordo com Kövecses (2002), dentro da teoria da metáfora conceptual é possível sintetizar os principais domínios-fonte e os principais domínios-alvo. São domínios-fonte de acordo com Kövecses (2002, p. 16-19):

a. "O corpo humano. Ex: O cabeça do departamento".

b. "Saúde e doença. Ex: uma sociedade saudável; uma mente doente. Ela feriu meus sentimentos".

c. "Plantas. Ex: O fruto de seu trabalho. Ele cultivou sua amizade com ela". 
Lidiane Melo de Souza \& Monica Fontenelle Carneiro

d. "Prédios e construções. Ex: Ela construiu um argumento coerente. Ele está financeiramente em ruínas".

e. "Máquinas e ferramentas. Ex: A máquina da democracia. Ela produz um livro a cada ano".

f. "Jogos e esportes. Ex: Ele tentou dar um checkmate nela".

g. "Dinheiro e transações econômicas. Ex: Ela investiu muito no relacionamento. Eu tentei economizar um pouco de energia".

h. “Alimentação e comida. Ex: Qual sua receita para o sucesso?”

i. "Calor e frio. Ex: uma recepção fria; um acolhimento caloroso".

Com relação aos domínios-alvo, que são mais abstratos, são estes os principais (KÖVECSES, 2002, p. 21-24):

a) "Emoção: geralmente as emoções são compreendidas via metáforas de força. Ex: Ela estava cheia de alegria. Ela sentia-se completamente feliz".

b)“Desejo: O desejo é semelhante à emoção, sendo também compreendido via metáforas de força. Ele também pode ser compreendido via metáforas de calor. Ex: A jaqueta que eu vi na vitrine me empurrou para dentro da loja”.

c) "Moralidade (bondade, maldade, honestidade, honra, etc): São compreendidas em termos de domínios-fonte concretos, tais como: transações econômicas, força, luz e escuridão e orientação espacial. Ex: Ela resistiu à tempestade. Eu vou ressarci-lo por isso".

d)"Pensamento: O pensamento pode ser compreendido como trabalho ou em termos de percepção, como por exemplo, a visão. Eu vejo seu ponto de vista. Ele buscou em sua memória".

e) "Sociedade e nação: Modos comuns de compreender a sociedade e a nação envolvem os conceitos fonte de pessoa e família. Ex: países vizinhos; nação amigável".

f) "Política: Como política geralmente está relacionada a poder, costuma ser conceptualizada como força. No entanto, ela também pode ser compreendida via domínios-fonte de jogos, esportes, negócios e guerra. Ex: Ele forçou a oposição a agir daquela maneira. Várias brigas giram em torno do aborto".

g)"Economia: São geralmente compreendidos via domínios-fonte de construções, 
plantas, jornadas, movimento e direção. Ex: O crescimento da economia”.

h)"Relacionamento humano (amizade, amor, casamento): São geralmente compreendidos via metáforas de plantas, máquinas e construções. Ex: Eles construíram um casamento forte. Eles tiveram que trabalhar no relacionamento”.

i) "Comunicação: Compreendidos via metáforas de recipientes, objetos e envio. Ex: Ela me deu muita informação. Aquele é um parágrafo denso".

j. "Tempo: A maior metáfora para tempo é aquela de acordo com a qual o tempo é um objeto que se move. Ex: O natal está vindo em breve. O tempo passa rápido".

k. "Vida e morte: A vida é metaforicamente relacionada a dia, luz, calor e outras, enquanto a morte é vista como partida, noite, escuridão e frio. Ex: Vovô se foi. O bebê chegará em breve".

1. "Religião: Deus é conceptualizado como pessoa. Ex: O Senhor é Rei. Ele é o Bom Pastor. Deus é pai”".

m. "Eventos e ações: Compreendidos como movimento e força. Ex: Ela tem atingido seus objetivos na vida".

A teoria proposta por Lakoff e Johnson (2002) propõe ainda a existência de diferentes tipos de metáforas conceptuais. Como afirma Kövecses (2002), as metáforas conceptuais podem ser classificadas de acordo com sua convencionalidade, sua função, natureza e nível de generalidade.

A convencionalidade de uma metáfora está relacionada ao seu uso dentro de determinada comunidade linguística, ou seja, quanto mais estabelecida for uma determinada metáfora em uma comunidade, mais convencional ela é. São exemplos:

\footnotetext{
ARGUMENTO É GUERRA: Eu defendi meu ponto de vista.

AMOR É UMA JORNADA: Cada um de nós deve seguir seu caminho. TEORIAS SÃO CONSTRUÇÕES: Nós temos que construir uma nova teoria. IDEIAS SÃO COMIDAS: Eu não consigo digerir todos esses fatos. ORGANIZAÇÕES SOCIAIS SÃO PLANTAS: A empresa está crescendo rápido. VIDA É UMA JORNADA: Ele teve um avanço na vida (KÖVECSES, 2002, p. 30).
}

Com relação à função, Kövecses (2002) alega que as metáforas podem ser classificadas de acordo com a função cognitiva que elas apresentam. Nesse sentido, corroborando a tipologia proposta por Lakoff e Johnson (2002), ressalta que se destacam três grupos gerais de metáforas conceptuais: estruturais, ontológicas e orientacionais. A natureza 
Lidiane Melo de Souza \& Monica Fontenelle Carneiro

da metáfora está relacionada a determinados esquemas que estruturam a maioria de nossos conceitos abstratos metaforicamente.

Finalmente, no que se refere aos graus de generalidade da metáfora, Kövecses (2002) postula que as metáforas conceptuais podem ser classificadas em dois níveis de generalidade: o nível genérico e o nível específico. Metáforas como: VIDA É UMA JORNADA, ARGUMENTO É GUERRA, entre outras, estão no nível mais específico, enquanto metáforas como EVENTOS SÃO AÇÕES e GENÉRICO É ESPECÍFICO, estão no nível genérico. O nível genérico é um nível mais amplo de onde surgirão várias metáforas em nível mais específico. O nível genérico refere-se a um conjunto de metáforas em nível específico.

Outro aspecto importante a ressaltar está relacionado ao fato de que as metáforas conceptuais podem realizar-se não só na linguagem verbal, como também em muitas outras áreas da experiência humana, afinal, o sistema que governa nosso modo de experienciar o mundo, nosso modo de pensar e agir é metafórico. Kövecses (2002, p. 57), denomina essas manifestações de realizações das metáforas conceptuais. Cita como exemplos dessas realizações:

a) Filmes e atuação: filmes podem ser estruturados com base em metáforas conceptuais.

b) Desenhos, pinturas, esculturas e construções: uma metáfora comum feita pelas crianças é OBJETOS INANIMADOS SÃO PESSOAS.

c) Propagandas: A principal manifestação de metáforas conceptuais é nas propagandas. Kövecses (2002) cita como exemplo, as máquinas de lavar que são frequentemente apresentadas como boas amigas, conceito esse que é baseado na metáfora: ITENS PARA VENDER SÃO PESSOAS, que é um tipo de personificação. A metáfora: UMA MÁQUINA DE LAVAR É UMA AMIGA evoca nas pessoas as mesmas atitudes e sentimentos que elas têm com seus bons amigos.

d) Símbolos: Símbolos em geral ou símbolos culturais podem ser baseados em metáforas conceptuais enraizadas numa determinada cultura. Kövecses (2002) cita como exemplo o fogo que é um símbolo comum para a vida. Esse símbolo é a manifestação da metáfora: VIDA É FOGO.

e) Mitos: As metáforas conceptuais podem realizar-se em mitos de diversas maneiras. Uma dessas maneiras é quando uma metáfora funciona como um 
elemento chave em um mito.

f) Interpretação de sonhos: Muito da interpretação dos sonhos depende de metáforas conceptuais cotidianas. Em outras palavras, sonhos realizam combinações particulares de metáforas.

g) Interpretação da história: Fatos históricos como guerras, revoluções, podem ser compreendidos via metáforas conceptuais.

h) Política e polícia estrangeira: O uso de metáforas conceptuais é muito comum na política. Segundo Kövecses (2002), na política americana, por exemplo, tanto o pensamento político como seu discurso são, na maioria das vezes, estruturados pelas seguintes metáforas: POLÍTICA É GUERRA, POLÍTICA É NEGOCIAÇÃO, SOCIEDADE É UMA FAMÍLIA, SOCIEDADE É UMA PESSOA e ELEIÇÃO PRESIDENCIAL É UMA CORRIDA.

i) Moralidade: Kövecses (2002) diz que o discurso sobre moralidade envolve duas metáforas conceptuais: MORALIDADE É FORÇA e MORALIDADE É VIRTUDE.

j) Instituições sociais: Algumas instituições sociais também podem ser baseadas em metáforas conceptuais.

k) Práticas sociais: Algumas metáforas podem criar práticas sociais. Uma delas é a metáfora VER É TOCAR. Essa é a metáfora no trabalho quando dizemos coisas como: Ele não consegue tirar os olhos dela.

1) Literatura: Para Kövecses (2002) essa é a área mais óbvia onde podemos encontrar metáforas conceptuais. A literatura geralmente faz uso de expressões metafóricas não convencionais que são baseadas em metáforas conceptuais convencionais.

Dessa forma, muitas metáforas conceptuais têm correlação com as experiências humanas. A teoria da metáfora conceptual trouxe grandes inovações ao estudo da metáfora, principalmente por incluir a importância do contexto, da cultura e acima de tudo, do pensamento, na compreensão das expressões metafóricas. A linguagem cotidiana recorre frequentemente a expressões metafóricas que são compreendidas como sinais do pensamento de uma pessoa que, na maioria das vezes, faz uso de metáforas de modo inconsciente, afinal, 
Lidiane Melo de Souza \& Monica Fontenelle Carneiro

este processo é inerente ao seu próprio pensamento. Assim, a análise das expressões metafóricas presentes no discurso cotidiano nos permite perceber que nos apoiamos em modelos do mundo concreto para conceptualizar fenômenos abstratos e que a metáfora linguística só é concretizada porque existem metáforas no nosso sistema conceptual, o que demonstra a centralidade dessas metáforas na vida cotidiana e sua influência em nossa forma de pensar e agir no mundo.

\section{REVELANDO SENTIDOS ATRAVÉS DA METÁFORA COMO FERRAMENTA PERSUASIVA NO DISCURSO JURÍDICO}

O discurso jurídico é fundamentalmente persuasivo, na medida em que, no Direito, o argumento está relacionado com o convencimento e com a fundamentação nas decisões judiciais. O uso persuasivo da linguagem tem por objetivo harmonizar elementos racionais e emocionais. Dada sua natureza controvertida e a riqueza semântica na área do Direito, a metáfora assume uma posição de destaque nos estudos do discurso jurídico. Uma característica dessa figura é a sua capacidade de mediação entre os meios conscientes e inconscientes de persuasão, ou seja, entre a cognição e a emoção. Em virtude de sua capacidade de ativar relações emocionais inconscientes, a metáfora seria capaz de influenciar nossas crenças, atitudes e valores de forma a possibilitar a transferência de associações positivas ou negativas de um domínio mais concreto para um domínio mais abstrato.

Charteris-Black (2004), ressalta que a metáfora apresenta ainda uma característica pragmática, qual seja, a de ser motivada pelo propósito subjacente de persuadir outrem. Esse funcionamento da metáfora como ferramenta persuasiva pode ser intensificado se essa figura estiver inserida em um cenário, metafórico ou não.

A linguagem jurídica apresenta determinadas características que a distanciam da linguagem cotidiana e a tornam, muitas vezes, praticamente ininteligível para os leigos. Para aqueles que não pertencem às comunidades que dominam e fazem uso desse discurso, este pode apresentar um estilo de redação considerado floreado e tortuoso, abundante em palavras de difícil compreensão, brocardos latinos e intermináveis sentenças, de forma que, muitas vezes, a informação principal de um texto acaba se perdendo no meio de tantas informações aparentemente irrelevantes (SCHOCAIR, 2008).

Antes de prosseguirmos com a discussão sobre nossos resultados, faz-se necessário 
definir nosso corpus.

\section{DEFINIÇÃO DO CORPUS E METODOLOGIA ADOTADA}

O corpus da nossa pesquisa é o voto da Ministra Relatora Nancy Andrighi, no julgamento do RECURSO ESPECIAL No 1.735.712 - SP (2018/0042899-4), pelos membros da Terceira Turma, do Superior Tribunal de Justiça, em 19 de maio de 2020, cuja ementa segue na transcrição abaixo (BRASIL, 2020):

CIVIL E PROCESSUAL CIVIL. RECURSO ESPECIAL. AÇÃO DE OBRIGAÇÃO DE FAZER E DE INDENIZAÇÃO DE DANOS MORAIS. RETIRADA DE CONTEÚDO ILEGAL. EXPOSIÇÃO PORNOGRÁFICA NÃO CONSENTIDA. PORNOGRAFIA DE VINGANÇA. DIREITOS DE PERSONALIDADE. INTIMIDADE. PRIVACIDADE. GRAVE LESÃO.

1. Ação ajuizada em 17/07/2014, recurso especial interposto em 19/04/2017 e atribuído a este gabinete em 07/03/2018.

2. O propósito recursal consiste em determinar os limites da responsabilidade de provedores de aplicação de busca na Internet, com relação à divulgação não consentida de material íntimo, divulgado antes da entrada em vigor do Marco Civil da Internet.

3. A regra a ser utilizada para a resolução de controvérsias deve levar em consideração o momento de ocorrência do ato lesivo ou, em outras palavras, quando foram publicados os conteúdos infringentes: (i) para fatos ocorridos antes da entrada em vigor do Marco Civil da Internet, deve ser obedecida a jurisprudência desta corte; (ii) após a entrada em vigor da Lei 12.965/2014, devem ser observadas suas disposições nos arts. 19 e 21 . Precedentes.

4. A 'exposição pornográfica não consentida', da qual a 'pornografia de vingança' é uma espécie, constituiu uma grave lesão aos direitos de personalidade da pessoa exposta indevidamente, além de configurar uma grave forma de violência de gênero que deve ser combatida de forma contundente pelos meios jurídicos disponíveis.

5. Não há como descaracterizar um material pornográfica apenas pela ausência de nudez total. Na hipótese, a recorrente encontra-se sumariamente vestida, em posições com forte apelo sexual.

6. O fato de o rosto da vítima não estar evidenciado nas fotos de maneira flagrante é irrelevante para a configuração dos danos morais na hipótese, uma vez que a mulher vítima da pornografia de vingança sabe que sua intimidade foi indevidamente desrespeitada e, igualmente, sua exposição não autorizada the é humilhante e viola flagrantemente seus direitos de personalidade.

7. O art. 21 do Marco Civil da Internet não abarca somente a nudez total e completa da vítima, tampouco os 'atos sexuais' devem ser interpretados como somente aqueles que envolvam conjunção carnal. Isso porque o combate à exposição pornográfica não consentida - que é a finalidade deste dispositivo legal - pode envolver situações distintas e não tão óbvias, mas que geram igualmente dano à personalidade da vítima.

8. Recurso conhecido e provido. (REsp 1735712/SP, Rel. Ministra NANCY ANDRIGHI, TERCEIRA TURMA, julgado em 19/05/2020, DJe 27/05/2020). (BRASIL, 2020).

O fato que ensejou o julgamento da nossa análise aconteceu no ano de 2013 , quando 
Lidiane Melo de Souza \& Monica Fontenelle Carneiro

uma mulher teve "[...] materiais íntimos - isto é, fotos -, em que aparece totalmente nua ou sumariamente vestida com biquínis ou adornos sexuais, que foram originalmente tiradas por um antigo parceiro ou namorado" (BRASIL, 2020). Após o final desse relacionamento, as fotos foram publicadas em um perfil existente na rede social mantida pelo Facebook. Ou seja, trata-se da análise de um "[...] típico caso de pornografia de vingança cometido por antigo parceiro" (BRASIL, 2020).

A ação foi ajuizada em 17 de julho de 2014 e o Recurso Especial, objeto da nossa análise, foi interposto em 19 de abril de 2017, sendo julgado em 19 de maio de 2020, após quase 6 anos e outros dois julgamentos anteriores nas instâncias inferiores. Pretende a autora a condenação da Facebook Serviços Online do Brasil para a remoção de determinadas imagens divulgadas em suas páginas e o pagamento de indenização pelos danos causados pela divulgação não consentida de fotos com nudez.

O corpus selecionado para análise consistiu na decisão da Ministra Nancy Andrighi, em que reconheceu, a favor da autora, que o fato de o rosto da vítima não estar evidenciado nas fotos de maneira flagrante é irrelevante para a configuração dos danos morais na hipótese, uma vez que a mulher vítima da pornografia de vingança sabe que sua intimidade foi indevidamente desrespeitada e, igualmente, sua exposição não autorizada lhe é humilhante e viola flagrantemente seus direitos de personalidade. $\mathrm{O}$ texto foi trabalhado manualmente e inúmeras expressões metafóricas identificadas. Essas marcas linguísticas foram associadas às seguintes metáforas conceptuais subjacentes:

1) DECISÃO JUDICIAL É FORÇA.

2) ARGUMENTO É CONSTRUÇÃO.

3) TRIBUNAL É PESSOA.

4) ARGUMENTO É GUERRA.

5) DECISÃO JUDICIAL É TRANSAÇÃO COMERCIAL

A partir de observações, ainda não teoricamente respaldadas no início dessa pesquisa, formulamos a hipótese de que a metáfora conceptual revela sentidos no discurso jurídico, especialmente no que tange à argumentatividade e à persuasividade desse discurso, realçando os pensamentos não revelados de forma intencional.

A motivação para a formulação de tal hipótese deu-se em virtude do fato de as metáforas conceptuais relacionadas ao discurso jurídico servirem para desvendar os 
argumentos não explicitados na defesa de uma tese. A metáfora conceptual licenciaria expressões linguísticas que enquadrariam a decisão judicial considerando o seu caráter persuasivo.

Parte das evidências linguísticas encontradas em nosso corpus possibilitou a confirmação dessa hipótese embrionária. Apresentamos, a seguir, algumas das evidências linguísticas encontradas no documento analisado que confirmaram a nossa hipótese.

A metáfora conceptual DECISÃO JUDICIAL É FORÇA licencia parte das expressões linguísticas no corpus analisado. Essa metáfora evidencia claramente que o conceito decisão judicial, mais abstrato, é parcialmente estruturado e entendido em termos de força, mais concreto. Trata-se de uma metáfora estrutural que, segundo esclarecem Lakoff e Johnson (2002, p. 134), permite que se use "[...] um conceito detalhadamente estruturado e delineado de maneira clara para estruturar outro conceito".

Dessa forma, a metáfora conceptual DECISÃO JUDICIAL É FORÇA permite que experienciemos uma decisão jurídica em termos de um ato físico, em que um ato judicial obriga o fim de uma disputa quando uma parte cria resistência a satisfazer a pretensão da outra. Utilizamos expressões linguísticas do domínio força para falarmos do domínio referente às questões judiciais.

Ao longo da pesquisa, percebemos que essas metáforas apareciam, muito frequentemente, inseridas em cenários metafóricos que funcionavam como intensificadores de seu valor semântico. Discutiremos, brevemente, as metáforas de força encontradas em nosso corpus (BRASIL, 2020).

1) DECISÃO JUDICIAL É FORÇA:

[...] o recurso não foi admitido na origem;

Desta forma, não há como reconhecer ilicitude na conduta dos prepostos do requerido, quando à própria autora caberia o ajuizamento de ação visando compelir o requerido à retirada do conteúdo que ainda classificava como ofensivo;

[...] é imperioso reconhecer a desnecessidade de ordem judicial para tornar a provedora de aplicações subsidiariamente responsável pelo conteúdo disponibilizado on-line;

Forte nessas razões, conheço do recurso especial e dou-lhe provimento, com fundamento no art. $255, \S 4^{\circ}$, III, do RISTJ;

[...] condenou a recorrida à 'exclusão [de perfis] liminarmente deferida (fls. 36), enquanto inocorrida a demonstração da licitude da divulgação da imagem impugnada pela autora, quanto no pagamento, para a autora, de indenização por dano imaterial (...)' (e-STJ fl. 239), cujo valor de reparação fixa estabelecido em R $\$ 20.000,00$ (vinte mil reais);

STJ havia firme jurisprudência segundo a qual o provedor de aplicação passava a ser solidariamente responsável a partir do momento em que fosse de qualquer forma notificado pelo ofendido; 
Lidiane Melo de Souza \& Monica Fontenelle Carneiro

Outra dificuldade adicional é o fato de não haver legislação específica sobre o assunto na data da ocorrência dos fatos, pois o Marco Civil da Internet foi publicado apenas em 23/04/2014, tornando-se vigente apenas sessenta dias depois, por força de seu art. 32;

$\mathrm{Na}$ hipótese em julgamento, a adolescente foi vítima de 'exposição pornográfica não consentida’ e, assim, é cabível para sua proteção a ordem de exclusão de conteúdos [...]. (BRASIL, 2020).

Nos trechos em destaque, verifica-se que o domínio-fonte FORÇA é identificado demonstrando que o processo judicial se desenvolve em busca do domínio-alvo DECISÃO JUDICIAL que seja firme, seguro, forte, imperioso, que ordene o fim da disputa.

No caso, a empresa Facebook foi omissa, apesar dos diversos pedidos da autora para que fossem excluídas da sua página as fotos em que aparecia a sua imagem em trajes sensuais, sem o seu consentimento, tendo a empresa Facebook realizado a exclusão do material somente após a ordem judicial. A decisão judicial enfrentou os argumentos de ambas as partes, posicionando-se firmemente em favor de uma delas, determinando a retirada do material divulgado consistente na imagem da autora em trajes pornográficos e, ainda, condenando a empresa Facebook ao pagamento de indenização pela prática de ato ofensivo à imagem da autora.

De outra banda, em várias passagens do texto, verifica-se a metáfora conceptual ARGUMENTO É CONSTRUÇÃO, em que experienciamos o domínio-fonte CONSTRUÇÃO como ato concreto de ARGUMENTO, comparando-se a habilidade argumentativa nos discursos utilizados pelas partes, como também o esforço dos fundamentos na decisão judicial ora analisada, com termos de construção. Vejamos os exemplos extraídos do nosso corpus:

2) ARGUMENTO É CONSTRUÇÃO:

[...] para reformar o acórdão recorrido e restabelecer a sentença do Juízo de $1^{\circ}$ grau de jurisdição;

Pretensão sustentada por suposta omissão na retirada de conteúdo;

Sustenta, ademais, a existência de dissídio jurisprudencial;

Assim, nos termos da jurisprudência do STJ antes da entrada da mencionada lei, não atendida uma solicitação extrajudicial - pelos canais fornecidos pela plataforma - para a retirada de conteúdo ofensivo, o provedor se torna responsável por danos morais suportados pela pessoa negativa afetada pelo material;

Manutenção da determinação de exclusão do conteúdo impugnado pela autora [...]. (BRASIL, 2020).

É relevante pontuar que a decisão judicial analisada foi proferida pelos membros da Terceira Turma do Superior Tribunal de Justiça, sendo esta a terceira decisão ao longo do processo. O Superior Tribunal de Justiça é hierarquicamente superior aos outros dois órgãos 
que também proferiram decisão no processo, sendo, portando, a sua decisão a que deve prevalecer. Considerando a superioridade do TRIBUNAL em questão, constatamos algumas passagens no texto analisado em que a metáfora conceptual TRIBUNAL É PESSOA está presente. O domínio-fonte PESSOA, ato concreto, é experienciado para caracterizar o domínio-alvo TRIBUNAL, enfatizando o posicionamento dos membros da Corte sobre outros julgamentos de fatos semelhantes ao que está sendo analisado e ainda sobre a sua posição em relação aos julgamentos anteriores no mesmo processo, conforme as descrições seguintes (BRASIL, 2020):

\section{3) TRIBUNAL É PESSOA:}

[...] Tribunal julgou parcialmente procedente o pedido para condenar a recorrida;

Tribunal de origem deu provimento ao recurso;

Embargos de declaração opostos pela recorrente foram rejeitados pelo Tribunal de origem;

[...] esta Terceira Turma já se pronunciou no sentido da não aplicabilidade do Marco Civil da Internet a fatos pretéritos a sua entrada em vigor, restando hígidas, nessas hipóteses, a jurisprudência do STJ quanto à fixação da responsabilidade de provedores de aplicação por conteúdo gerado por terceiro;

Terceira Turma teve a oportunidade de analisar com cuidado os detalhes e contornos da exposição pornográfica não consentida e como esse tipo de divulgação causa prejuízos às pessoas expostas;

$\mathrm{O}$ Tribunal de origem, contudo, deu provimento à apelação da recorrida ao entender que material pornográfico seria apenas aquele que mostrasse a vítima da exposição totalmente nua;

[..] segundo o Tribunal de origem, a recorrente encontra-se sumariamente vestida, em posições com forte apelo sexual;

Ao contrário da interpretação conferida pelo Tribunal de origem, o art. 21 do Marco Civil da Internet não abarca somente a nudez total e completa da vítima [...]. (BRASIL, 2020).

Também está presente no texto analisado a metáfora conceptual ARGUMENTO É GUERRA, em trechos que demonstram as partes na ação judicial em situação de combate, como adversários, em oposição, lutando com suas armas, na defesa dos seus argumentos em busca da vitória, conforme se verifica adiante:

\section{4) ARGUMENTO É GUERRA:}

[...] existência de dissídio jurisprudencial;

Ou seja, tem-se sob análise um típico caso de pornografia de vingança cometido por antigo parceiro;

A 'exposição pornográfica não consentida', da qual a 'pornografia de vingança' é uma espécie, constituiu uma grave lesão aos direitos de personalidade da pessoa exposta indevidamente, além de configurar uma grave forma de violência de gênero que deve ser combatida de forma contundente pelos meios jurídicos disponíveis;

Isso porque o combate à exposição pornográfica não consentida - que é a finalidade deste dispositivo legal - pode envolver situações distintas e não tão óbvias, mas que gera 
Lidiane Melo de Souza \& Monica Fontenelle Carneiro

igualmente dano à personalidade da vítima;

As discussões acerca da responsabilidade civil dos provedores de aplicações apresentam uma complexidade elevada, pois em regra não se está a discutir uma ofensa diretamente causada pelo provedor, mas sim por terceiros usuários das funcionalidades por ele fornecidas [...]. (BRASIL, 2020)

Apesar de não haver um combate real entre as partes, uma verdadeira batalha metafórica evidencia-se nos exemplos destacados. A autora e a empresa Facebook, no contexto da ação jurídica aqui em foco, experienciam-se um ao outro como adversários, oponentes, o que fica claro na análise das marcas linguísticas apresentadas em seus argumentos, sendo a decisão judicial o ponto final, a solução dessa disputa de interesses. Um ataca a posição do outro enquanto defende a sua própria, tentando fazer seu oponente renderse ou levá-lo à derrota.

Prosseguiremos, agora, com algumas marcas linguísticas referentes à decisão judicial, sendo observada a presença da metáfora conceptual DECISÃO JUDICIAL É TRANSAÇÃO COMERCIAL, registrando, no entanto, que essa metáfora não se manifesta de forma predominante no texto. Vejamos (BRASIL, 2020):

\section{5) DECISÃO JUDICIAL É TRANSAÇÃO COMERCIAL:}

[...] Ação de obrigação de fazer cumulada com indenização de danos morais; Partilha dos ônus de sucumbência;

O propósito recursal consiste em determinar os limites da responsabilidade de provedores;

Para o correto deslinde deste julgamento, é necessário ressaltar alguns contornos da hipótese dos autos;

A dificuldade é ainda mais elevada quando os provedores não exercem nenhum controle prévio sobre aquilo que fica disponível on-line, o que afasta a responsabilidade editorial sobre as informações;

O propósito recursal reside na definição do termo inicial da responsabilidade solidária da recorrente;

Sobre os provedores de aplicação, incide a tese da responsabilidade subjetiva, segundo a qual o provedor de aplicação torna-se responsável solidariamente com aquele que gerou o conteúdo ofensivo se, ao ser notificado a respeito da lesão, não tomar providências para a sua remoção;

Com o advento da Lei 12.965/2014, o termo inicial da responsabilidade do provedor de aplicação foi postergado no tempo [...]. (BRASIL, 2020).

Nesse contexto, a decisão judicial é experienciada no sentido de definir as responsabilidades de cada parte, os seus limites de atuação e as consequências da sua inobservância, tal como se estabelece em um contrato mercantil.

Através da nossa análise, percebemos que os domínios-fonte FORÇA, CONSTRUÇÃO, PESSOA, GUERRA e TRANSAÇÃO COMERCIAL serviram de base 
conceptual para as expressões linguísticas que estruturaram o discurso jurídico na decisão judicial, conforme os exemplos apresentados. As expressões relativas à força, construção, pessoa, guerra e transação comercial, destacadas no texto, são utilizadas na argumentação e na persuasão do discurso na decisão judicial analisada, contribuindo para que o locutor, mesmo que inconscientemente, deixe pistas sobre como determinados eventos, pessoas envolvidas no processo e suas ações, são percebidos por ele.

Cada escolha lexical feita nos revela, mais diretamente, como o locutor encoraja os outros a pensar sobre os fatos de um processo, das partes adversárias e do desfecho da controvérsia. Na medida em que a intenção dos operadores do direito é a de convencer o leitor da verdade por meio da sua argumentação, o uso das metáforas conceptuais pode converter-se em uma ferramenta poderosa.

\section{CONSIDERAÇÕES FINAIS}

Este estudo teve como proposta investigar o papel da linguagem metafórica no discurso jurídico. Para tanto, a decisão proferida pela Ministra Relatora Nancy Andrighi, no julgamento do RECURSO ESPECIAL No 1.735.712 - SP (2018/0042899-4), em 19 de maio de 2020, relativa a um processo sobre a divulgação, nas redes sociais, de fotos íntimas da vítima, sem o seu consentimento, pelo antigo parceiro, por motivo de vingança, constituiu o corpus analisado.

A avaliação dos resultados da pesquisa indicou a relevância do uso de expressões metafóricas e particularmente os de força, construção, pessoa, guerra e transação comercial, para promover a argumentatividade e a persuasividade do texto jurídico.

Foram identificadas em nosso corpus várias expressões de força, construção, pessoa, guerra e transação comercial, todas marcadas linguisticamente.

Nos trechos destacados, verifica-se que o tribunal julgador se personifica através de expressões linguísticas que o identificam como pessoa, a argumentação no discurso jurídico foi desenvolvida por meio de metáforas de construção, em que ficou revelado que as partes se encontram em posição de oposição na ação judicial, por meio das expressões de guerra, bem como que a decisão judicial estabelece os limites da responsabilidade de cada litigante envolvido, como se percebe nas expressões de transação comercial, e que a decisão judicial tem o papel de impor uma solução à discórdia travada pelos adversários, conforme as 
Lidiane Melo de Souza \& Monica Fontenelle Carneiro

expressões de força utilizadas no nosso corpus.

Segundo nos sugerem Lakoff e Johnson (2002, p. 53) “A própria sistematicidade que nos permite compreender um aspecto de um conceito em termos de outro (...) necessariamente encobrirá outros aspectos desse conceito". Assim, percebemos, por meio do texto analisado, que o operador do direito faz uso da linguagem de forma a direcionar a compreensão de seu interlocutor da maneira que melhor lhe convier, focalizando determinados aspectos e impedindo que outros aspectos, inconsistentes com as metáforas propostas, sejam considerados. Cabe ao interlocutor assumir uma postura mais crítica no sentido de entender que determinado conceito está sendo apenas parcialmente estruturado, o que nem sempre é uma tarefa fácil, mas necessária, particularmente na posição de um magistrado, que deverá proferir uma decisão fundamentada na apresentação de evidências e na argumentação jurídica.

Por tudo o que foi tratado, verifica-se que as metáforas conceptuais revelam sentidos no discurso jurídico e são capazes de subsidiar uma melhor compreensão argumentativa e persuasiva desse discurso.

\section{REFERÊNCIAS}

ABRANTES, Ana Margarida. Da vida e outras viagens... A relevância das metáforas conceptuais na abordagem de uma língua estrangeira. Máthesis, Viseu, n. 10, 2001.

BRASIL. Superior Tribunal de Justiça - STJ. Recurso Especial No 1.735.712 - SP (2018/0042899-4). Disponível em: https://scon.stj.jus.br/SCON/jurisprudencia/toc.jsp? livre $=$ FACEBOOK+E+EXPOSI\%C7\%C3O+DE+VINGAN\%C7A\&b=ACOR\&thesaurus=JU RIDICO\&p=true. Acesso em: 06 jul. 2020.

CHARTERIS-BLACK, Jonathan. Politicians and Rhetoric: The Persuasive Power of Metaphor. Palgrave, 2004.

FETZNER, Néli Luiza Cavalieri. Argumentação Jurídica - Teoria e Prática. 4. ed. Rio de Janeiro: Freitas Bastos Editora, 2012.

KÖVECSES, Zoltán. Metaphor - A Practical Introduction. Oxford: OUP, 2002.

LAKOFF, George; JOHNSON, Mark. Metáforas da vida cotidiana. Tradução Grupo GEIM. São Paulo: Educ; Campinas: Mercado de Letras, 2002.

REDDY, Michael J. The conduit metaphor. In: ORTONY, A. (Ed.). Metaphor and Thought. Cambridge: Cambridge University Press, 1979. 
SARDINHA, Tony Berber. Metáfora. São Paulo: Parábola Editorial, 2007.

SCHOCAIR, Nelson Maia. Português Jurídico. Rio de Janeiro: Elsevier, 2008. 